\title{
Naïve Panentheism
}

\author{
Karl Pfeifer
}

\section{In-troduction}

What is panentheism? The term »Panentheismus « was coined by Karl Krause in $1828,{ }^{1}$ reflecting the Greek expression $\pi \hat{\alpha} \nu \varepsilon^{2} \nu \Theta \varepsilon o ́ s$ (pân en Theós), which literally means »all in God «. It is often said that panentheism stands midway between theism and pantheism, melding the transcendence of God from theism with the immanence of God from pantheism. Whereas theism regards God as standing independent of the world, pantheism regards God and the world as coextensive or identical, and panentheism regards God as containing the world; the world is in God, hence God is more than the world (transcendence), but God is also present in the world (immanence).

The word »in« is central here and needs to be clarified. It has been claimed that various panentheist positions entail different meanings of »in « and Tom Oord has been credited with putting together an illustrative list. ${ }^{2}$ Supposedly, the world is »in« God because:

1. that is its literal location

2. God energizes the world

3. God experiences or »prehends« the world (process theology)

4. God ensouls the world

5. God plays with the world (Indic Vedantic traditions)

6. God »enfields« the world (J. Bracken)

7. God gives space to the world (J. Moltmann ... zimzum tradition ...)

8. God encompasses or contains the world (substantive or locative notion)

9. God binds up the world by giving the divine self to the world

1 Krause 1828: 256. Although Clayton 2010: 183 alleges that Friedrich Schelling prefigured Krause's 1829 [sic] coinage of the term »Panentheismus « with his use of the phrase »Pan+en+theismus« in his Essay on Freedom in 1809, that phrase (with or without the pluses) does not appear in the original German text, nor does »Pan+en+theism « (with or without the pluses) appear in any of the English translations; cf. Göcke 2013a: n. 5. A possible even earlier use by Krause awaits verification: in his foreword to Vorlesungen über das System der Philosophie, Krause tells us (pp. v-vi) that his System der Wissenschaft is unaltered (»unverändert dasselbe «) from his teaching lectures of 1803-04 in Jena and that his Entwurf des Systemes der Philosophie of 1804 bears witness thereto. For the first study of Krause's panentheism in English, see Göcke 2018.

2 Clayton 2004: 253 . 
10. God provides the ground of emergences in, or the emergence of, the world $[\ldots]$

11. God befriends the world [...]

12. All things are contained »in Christ « (from the Pauline en Christo)

13. God graces the world [...]

I am not convinced. Except for 1 and 8, the »becausal« relata per se seem to have nothing to do with the meaning of »in« at issue, and it is not obvious that in most of these cases a plausible connection to in-ness cannot be given in terms of a longer explanation involving a locative use. Here is how I would rate the list:

- Satisfactory becausal relations (i.e. ones that actually involve a recognizably straightforward meaning of »in«): 1,8

- Unsatisfactory becausal relations: 2, 3, 5, 7, 9, 10, 11, 13

- Maybes: 4, 6, 12

Let us first consider the Unsatisfactories:

2. God energizes the world. By itself, this does not require the world to be in God; an analogy: an electronic device may be energized by an external power source (e.g. electrical outlet) or an internal power source (e.g. battery); only rarely would an electronic device be contained within its power source, if at all.

3. God experiences or »prehends« the world. Experiences and prehensions are not confined to internals (cf. proprioception) but may be of externals (cf. perception).

5. God plays with the world. Prima facie this suggests that God and the world are ontologically distinct, inasmuch as playthings are typically external to players. In the Heliopolitan creation myth, Atum does »play with himself« but that does not support a world-in-God interpretation or outcome.

7. God gives space to the world. »Giving space to« or »making space for« can be construed as forming an internal space or an external space. However, since the central concept of the tzimtzum tradition is contraction (»tzimtzum « means »contraction«) for the purpose of making the space in which creation of the world can take place, prima facie giving space to the world does not seem to put the world into God.

9. God binds up the world by giving the divine self to the world. One can bind up something that is either internal or external to oneself, but giving oneself to the world suggests the world is external.

10. God provides the ground of emergences in, or the emergence of, the world [...]. God could presumably provide this whether the world is in him or not. 
11. God befriends the world; 13. God graces the world. Again these do not preclude the world's being external rather than internal to God.

Now for the Maybes:

4. God ensouls the world. If the »en« of »ensoul« works like the »en« of »envelop«, then there is a semantic linkage to »in « that implies the world's being in God. However, if we go with the Oxford English Dictionary's secondary definition of »ensoul « as »to infuse a soul into « then ensouling could be either internal or external.

6. God »enfields« the world. Because this claim is associated with Joseph Bracken, the notion of enfielding here is one that derives from psychological field theory, ${ }^{3}$ an offshoot of Gestalt psychology. In psychological field theory interactions between individuals and environments are central, and the totality of a person's experiences and needs and all the environmental factors that influence the person's behavior at any time is called a »life space« or »psychological field «. Psychological field theory also uses topological notions in describing the various interconnections within the totality. Hence, psychological field theory deploys spatial metaphors that might provide an appropriate sense of in-ness. However, it is not clear whether Bracken's take on fields considers God to be coextensive with a field that is all-enfielding or whether the field is confined to the world. ${ }^{4}$

12. All things are contained »in Christ (from the Pauline en Christo). This one strikes me as an outlier, not so much wrong as irrelevant, perhaps using $»$ in « in a doxastic sense of participating-in-a-community-of-ideas or of havingfaith-in; or a social sense of being-together-in-fellowship (cf. the salutation »Yours in Christ«). To momentarily change gears, rather than implying anything spatial or locative, 12 seems more on the order of what a party faithful might tell a comrade: »Everything is contained in Marx.« To be sure, there are some biblical passages that are more amenable to a spatial or locative construal than this, although it is noteworthy that the »things« typically referred to are the believers in Christ and not the inventory of the world at large. (But that may be enough for a clever spin doctor to get started.)

Benedikt Göcke has instructively generalized the problems he sees with what I have listed as Unsatisfactories and Maybes with his observation that »almost any interpretation of >in< that understands the relation between God

3 Britannica 2016.

4 Bracken 2000: 7f. says, for example, »in line with this proposal one can postulate that the universe or cosmic process is at any given moment an all-encompassing sstructured society< or structured field of activity for all the actual entities emergent within it.« [...] »God shares, in other words, a common field of activity with finite actual entities.« 
and everything else as an internal and intimate relation between God and everything else can also be thought of as an external and intimate relation, and vice versa. « ${ }^{5}$ As is evident from my own assessments, I don't disagree with that. My problem, however, is with regarding a number of Oord's so-called meanings of »in« as being meanings of »in« in the first place, rather than simply being not relevantly qualified tenets of some variant of panentheism. »God graces the world « for example says absolutely nothing about in-ness or lack thereof, absolutely nothing about characterizing an internal or external relation. As a tenet of a variant of panentheism, it does not explain the in-ness of that variant; rather, what needs to be explained is how that tenet can be understood in terms of the in-ness of that variant of panentheism.

I don't believe a demarcation of panentheism that abandons the central locative or spatial characterization suggested by the etymology and the familiar diagrams (more on which below) or makes proprietary claims about any other properties of God not articulated in such terms is feasible. A clever theist could always appropriate such properties in some manner or other, and panentheists of different denominations could always find ways to disagree amongst themselves about such properties.

A constant across many popular contemporary portrayals of panentheism just is a spatial-locative characterization with accompanying diagrams. One may be naïve in holding that this constant directly provides us with a view of panentheism comme il faut, but that is where I will start and, after some scrutiny, grooming, and fattening thereof, abide. ${ }^{6}$

\section{Figuring »In« Out}

Let us then consider some diagrams commonly used ${ }^{7}$ to illustrative the differences between theism, panentheism, and pantheism:

5 Göcke 2013b: 63 .

6 This is somewhat like the naïveté of naïve realism. Or it could be regarded as akin to the naïveté of Friedrich Schiller's naïve poets, who in a childlike way accept what's given, as opposed to the sentimental poets, who place themselves reflectively and self-consciously apart, but may also strive for a synthesis (see his 1795-96 Über naive und sentimentalische Dichtung). Moreover, Sharpe 1991: 6o discerns a youthful vision of »optimistic panentheism« in Schiller's 1786 Theosophie des Julius. So I might with modest justification be said to be pursuing a Naïve and Sentimental Panentheism. :)

7 Although the diagrams, being diagrams, are perforce two-dimensional, it is easy enough to imagine analogous three-dimensional representations, and there is no reason that the basic distinctions being made couldn't be made in higher dimensional frameworks if need be, 


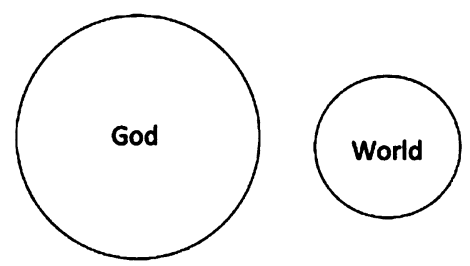

Theism

FIGURE 1

Figure 1 represents the fact that in theism, God and the world are different substances. The »world « is typically regarded as being the universe, but we can expand that conception by allowing other possibilities such as a multiverse or the »many-worlds« of that eponymous interpretation of quantum mechanics.

Some diagrams for theism also have an arrow connecting God and the world to indicate that God interacts with and intervenes in the world. Without an appropriate caption or emendation, Figure 1 could just as well be a diagram for the omni-absent God of deism. Let us represent God's interactive interface with the world with a point of contact between the circles, i.e. a common »pineal point« on their circumferences, as in Figure 1a:

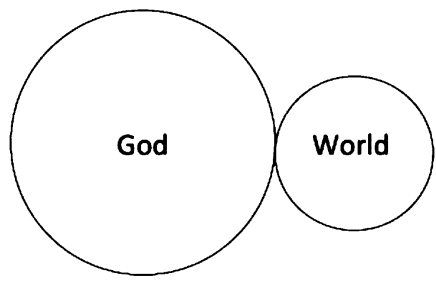

Theism

FIGURE 1A

although visualizations would be more difficult. Moreover, the regions the lines enclose don't have to be regarded as literally being bounded, although they could be, e.g. for the case of a finite universe; cf. Borg 1997: $5^{1}$ n. 2. 
Typical diagrams for panentheism and pantheism are:

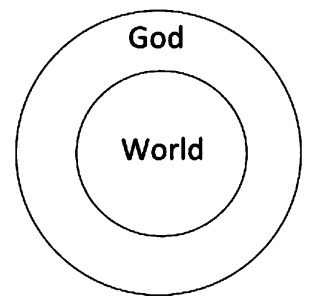

Panentheism

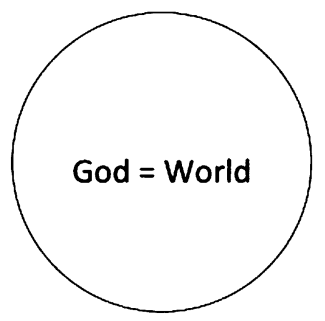

Pantheism

FIGURE 2

FIGURE 3

The two-dimensional doughnut of Figure 2 shows that the world is contained within God and we can consider God's interface with the world to be represented by a shared locus of points along the circumference of the inner circle. Alternatively, we might just represent the interface by single point of contact between the circumferences of the two circles, as in Figure za:

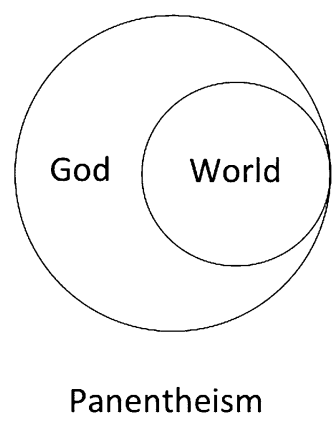

FIGURE 2A

But now an interesting question arises. Aren't Figures 2 and 2a ambiguous? Although the world is represented as being $» \mathrm{in} «$ God, there are two possibilities:

Case (i). The world is in God but the world is not a part of God.

Case (ii). The world is in God and the world is a part of God.

To make an analogy: My vermiform appendix is in me and is a part of me. However, the cherry pit I accidently swallowed is in me but is not a part of me. Based on these considerations, I submit that Figure 2a, Case (i) is tantamount to Figure 1a. If the world is not a part of God and we imagine the contact point 
as a hinge and swing the contained circle outward like a door, we in effect end up with Figure 1a. Opening the »door« wouldn't leave a circular hole in the big God circle, because after all if you take something out of God that isn't a part of God, all of God will still be there. Cf: if my appendix is surgically removed, less of my body will remain, but if I cough up and spit out the cherry pit, my body is still all there. The upshot is that "in « cannot be conceived as mere containment; panentheism requires parthood, otherwise it collapses into theism. ${ }^{8}$

So Figure 2a, Case (ii) is the more suitable option. Panentheism requires that the in-God-ness of the world be construed not only in a locative or spatial but also in a substantive sense.

R.T. Mullins has recently proposed a model of panentheism that embraces a spatial-locative reading of $»$ in $« .{ }^{9}$ Postulating a distinction between absolute (or metaphysical ${ }^{10}$ ) space and time and physical space and time, Mullins suggests that absolute space and time, but not physical space and time, be construed as attributes of God. »Absolute space and time exist regardless of the physical and temporal things that are contained within them« (p. 342). So in creating a universe, God creates physical space and time, but physical space and time exist in absolute (or metaphysical) space and time, and since absolute (or metaphysical) space and time are attributes of God, the universe is »literally in God « (p. 343). Mullins alleges that »Classical theists typically claim that God creates space and time and as such space and time are not attributes of God. Some neo-classical and open theists affirm that absolute time is a necessary concomitant of God's being (e.g. Clarke and Swinburne), but they do not insist that absolute space and time are divine attributes « (ibid.). If so, he alleges, we have a unique claim about panentheism that differentiates it from theism.

Mullins adds that his model also demarcates panentheism from pantheism, inasmuch as the panentheist »can maintain that God and the universe are distinct substances. God and the universe are not identical. The universe is not identical to absolute space and time; rather, the universe exists in absolute space and time. In identifying God and the universe, the pantheist is collapsing the distinction between absolute/metaphysical and physical space and time« (ibid.).

8 Some panentheists are prone to talk of the world as »God's body«. I would suggest that such a conception of the world actually makes more sense for theism. That's why I referred earlier to the interface between God and the world in Figure 1a as a »pineal« point. Mullins 2016.

10 Mullins 2016: 343 mentions a distinction sometimes made between metaphysical space and time and physical space and time; he suggests that, given this distinction, absolute space and time are to be construed as metaphysical space and time. 
His proposal, as Mullins himself admits, does leave unanswered questions. One concern might be a seeming equivocation between substance and attribute: God is a substance; the universe is a substance; absolute space and time are attributes; physical space and time (equated with the universe or containing the universe?) and the universe exist in absolute space and time. ${ }^{11}$ One might think absolute space and time are being treated both as substances and as attributes. Can a substance be attributed? (Aristotle and Frege say »no«.) Can an attribute contain a substance? (Perhaps when it's really a relation....) Purists will not be happy with such loose talk. And of course, one might also wonder, what's to stop a contrarian theist from defying Mullins and appropriating some of the claims he assigns to panentheists? ${ }^{12}$

Such concerns notwithstanding, I am sympathetic to Mullins's proposal, in spirit if not entirely in letter, because it could straightforwardly serve as a caption for Figures 2 and 2a. However, the discussion for those figures also indicates that Mullins's proposal does not go far enough. It could only serve as a necessary condition for differentiating panentheism from theism, since it does not distinguish between Cases (i) and (ii). For that, we also need to construe the in-ness of panentheism as substantive parthood; God and the universe cannot be completely distinct substances.

\section{The Dough in the Doughnut ${ }^{13}$}

Having plumped for a spatial-locative characterization of panentheism à la Mullins, albeit supplemented with substantive parthood, I will hereinbelow flesh it out with some analogies.

11 If the universe necessarily exists, then physical space and time, in addition to absolute space and time, could be considered to be attributes of God. Cf: When I have the attribute of having an alimentary canal, and the alimentary canal includes an esophageal passage, then ipso facto I have the attribute of having an esophageal passage. Similarly, if God has the attributes of absolute space and time, and absolute space and time (necessarily) contain physical space and time, then God could also be said to have the attributes of physical space and time. Moreover, if God can have contingent properties, then the universe doesn't even have to necessarily exist. Theological conceptual frameworks have a lot of wiggle room.

12 But I don't think it would be particularly contrarian for a theist to claim that absolute space and time are divine attributes. That no theists apparently have done so seems more like inadvertence.

13 A doughnut chart is a variant of the pie chart. Figure 2 isn't a doughnut chart, not even a bad disproportional one (cf. notes 21, 22); like the cartoon character Jessica Rabbit, it's »just drawn that way.« 
We have determined that Case (ii) is the viable option for panentheism. Although I made the comparison of panentheism and theism using Figures 1a and 2 a because the visual analogy was more direct, it should be clear that a Case (i) for the Figure 2 doughnut is equally tantamount to theism, despite the greater dissimilarity of Figures 1a and 2. To use a baseball metaphor, there is a distinction between the infield (the world) and the outfield (God), and although they are interrelated in the game of baseball, the infield is not part of the outfield.

Speaking of fields, the metaphor of a force field is also apt, and we can take some inspiration from Bracken's notion of »enfielding « (Maybes \#6, above) without adopting the baggage attached. What sort of force field, then? Let's first consider an ordinary magnet's magnetic field. Objects can be placed in a magnet's magnetic field, but with many kinds of substance, the field just passes through the object without having an effect on it. Witness the primary school science demonstration with a magnet under a sheet of paper and some iron filings on top. This demonstration could be an analogy for theism: the magnet (with attribute of magnetic force) $=$ God, the paper plus iron filings = the world; God and the world are discrete substances; God acts upon the world and produces some effects in it (the paper is not affected but the iron filings are). Although the world is in the magnetic field, it is not a part of it, so the magnetic-field analogy is captured by Figure 2 Case (i).

Consider, too, the fields as postulated by general field theories in physics, where the physical universe, with its physical attributes of space and time, is itself seen as one enormous, possibly infinite physical field, and where ordinary physical objects and phenomena are constituted by curvatures, distortions, perturbations, or whatnot, of the field. God, on a panentheist conception, is naturally not a physical field with physical attributes. But instead, we might conceive of him, in parallel fashion, as a spiritual field with Mullins's suggested divine attributes of absolute space and time. Indeed, regarding God as a spiritual field is one way of understanding the biblical assertion that »God is spirit« (John 4:24). ${ }^{14}$ In physics, forces are typically essentially allied to fields (hence »fields of force« or »force fields«), so the notion of a spiritual field can also be regarded as essentially allied to a notion of a spiritual force.

Let us then entertain a notion of God as an endless spiritual field that contains the world and of which the world is a part. Much like physicists' talk of matter consisting of perturbations in the physical field that constitutes or pervades the physical universe, we can think of the physical universe itself as a perturbation in the spiritual field that is God. Nor need we think of the

14 In some versions of the Bible, John 4:24 has »spirit« as a count noun: »God is $a$ spirit«. 
spiritual field as passive; it might be regarded as an intelligent force ${ }^{15}$ that wills its own perturbations, and such willings of perturbations would ipso facto be acts of creation. A »point « in the spiritual field might be expanded into a universe; in other words, God could will a Big Bang within himself. This would be akin to the power of materialization sometimes attributed to yogis, with God being like unto a super-yogi who can initiate and foster a benign tumor within himself.

Inasmuch as these universe-constituting perturbations are within and part and parcel of the spiritual field of force, we may also say that the world is ipso facto »enfielded « (Maybes \#6) by the spiritual field of force, viz. God. (If, alternatively, we were to think of the divine spirit as being more like the local magnetic field in a schoolroom science demonstration, i.e. like, insofar as the divine spirit merely permeates or passes through the world in the way that a magnetic field passes through an object that is within but not a part of the magnetic field, then we would default to some form of theism.)

Presumably if the all-pervading spiritual field is a mentating divine person, then it can also be regarded as a soul, in which case we might have a soul that »ensouls « the world (Maybes \#4). However, we might again ask about the role of the prefix »en«. Is it like the »en« of »enmired« (»stuck in or covered by mire [i.e. mud] «)? That would seem to suggest that what is ensouled is in the soul but is not a part of the soul, and that won't do here since it amounts to the situation represented in Figure 1a or Case (i) of Figure 2a. Moreover, it is odd to speak of anything that is nonmental as a part of the soul.

Some panentheists (as well as some pantheists) like to think of the world as God's body. But let's consider souls à la Cartesian dualism for a moment. A person with a soul is not at all ensouled in the sense of a soul containing a body or even of a body containing a soul. The situation is more like that of a person wearing a hat: during life the Cartesian soul accompanies but is not a part of the body (and vice versa). Clearly the relationship between the world and divine soul or spirit cannot be Cartesian if we are to stick with the spatiallocative construal of panentheism. If the relationship were Cartesian, it would be what is represented by Figure 1a or Case (i) of Figure 2a again.

However, if we think of a soul in its secondary sense of simply being a particular person, and think of a person as per Strawson's person theory, ${ }^{16}$ then a human person is something that has both a body and a mind, i.e. an en-

15 The all-pervading and conceivably intelligent force of the new religion of Jediism is often described in panentheistic terms. However, Jediism appears to have no tenets about creation or the modal status of the universe.

16 Strawson 1959: chap. 3. 
tity to which both physical and mental attributes can be ascribed but which is itself neither a physical body nor a mind-Strawsonian tripleism, ${ }^{17}$ as it were. Pursuing that analogy, we might think of God as a divine person/soul who has both spiritual attributes and physical attributes, the latter by virtue of being suitably related to the physical world. However, if that relation, to repeat our previously used metaphor, is pineal, then we are again no further ahead. An alternative might be to consider »ensouled « to be akin to »enabled«. But that merely suggests providing an additional quality rather than consisting in a locative or spatial relationship. The conclusion I draw at this point is that ensouling is not helpfully comparable to enfielding after all, and I therefore demote ensouling from the Maybes to the Unsatisfactories.

\section{Panning for Panpsychism}

Returning to the notion of enfielding, we may ask how panpsychism might figure in an enfielding scheme of things. Presumably if the all-pervading spiritual field is a mentating divine person, it would be a tautology that panpsychism is true: mentality is everywhere that that divinity is, namely everywhereincluding, by implication, the physical universe. Put another way, this construal of panpsychism would be true of the physical universe, and more besides.

Contemporary panpsychists and their fellow travellers will not likely be happy with such supernaturalization of panpsychism. Those folks regard panpsychism as a thesis about the physical universe, to wit that fundamental physical entities have genuine mental states. I myself am not drawn to the idea that »there is something that it is like to be a proton « (or whatnot) and therefore have no truck with the various panpsychisms that postulate or argue that the basic microphysical entities have primitive experiential/phenomenal properties or consciousness. However, I do think a significant analogy can be drawn between microphysical entities and the so-called unconscious mental states and processes that underpin or give rise to our conscious mental states and processes. There's a lot going on in the brain and even if unconscious, the fact that we often resort to a homuncular intentional stance to make sense of much of it is highly suggestive. Moreover, since physical causal-dispositional states satisfy various common criteria for intentionality, and dispositional properties attend everything physical, we can argue for panintentionalism, considered as

17 Cf. Martin 1969. 
a diluted variant of panpsychism. ${ }^{18}$ Physical intentional-dispositional states are everywhere and when arranged in complex arrays result in full-fledged intentional states. How do conscious phenomenal states arise? I lean towards the view that they consist of or in neurophysiological properties, states, or processes of the brain. These can be called emergent, but we need not decide here and now whether the emergence is like the weak emergence of water from its constituent elements or like the stronger emergence of property dualism.

Again we may ask how the God of panentheism figures in this scenario. There are two but not necessarily mutually exclusive possibilities. Given that the physical universe is a realm of cause and effect, we can regard the divine spirit as sustaining all worldly causal relationships, making the physical causal chains and intentional-dispositional configurations that result in mentality possible. ${ }^{19}$ Alternatively, we can opt for some form of occasionalism, whereby God intervenes to produce mental states whenever the underlying arrays of intentional causal-dispositional states are ripe for it. Moreover, God would accomplish either of these by enfielding, in the relevant sense, the world and willing the results. So just as causation in the world might be dependent on supernatural intentionality and willful causation, mentality in the world might likewise be dependent on supernatural intentionality and willful causation.

Thus we have two versions of panpsychism that are compatible with panentheism. The first is merely a consequence of God's all encompassing presence as a divine person who consists in a mentating spiritual field; as such, it is simply a restatement of an essential attribute of God. The other is a modest worldly panintentionalism, which by the grace of God yields conscious mental states at certain levels of complex organization of physical intentional causal-dispositional states. However, panintentionalism, as well as the various panpsychisms claiming primitive experiential/phenomenal properties or consciousness for the basic microphysical entities, would be an optional add-on as regards panentheism. Unlike the situation with pantheism, God is not identical to the world and therefore panentheism per se does not stand in need of a panpsychism that derives mentality from the physical.

18 I have presented these ideas in more detail in Pfeifer 2016. Is my panintentionalism the same as David Chalmers's panprotopsychism? According to Chalmers 2016: 31, »protophenomenal properties are special properties that are not phenomenal... . Panprotopsychism is then the view that some fundamental physical entities have protophenomenal properties.« Since he does not regard mere dispositional properties as appropriately special, the answer is »no«.

19 Cf. Copleston 1961: 118-120. 


\section{Another Inning}

So far we have focused on how the world might be in God. But God himself is everywhere, we are told in our catechisms. God is omnipresent and everpresent. So God is in the world and therefore presumably in each of us as well. I have previously suggested that in order to make some talk about God intelligible we need to recognize that the word $»$ God « is equivocal between a mass-noun sense and a count-noun sense. ${ }^{20}$ When used with a mass sense, it is similar to the term »gold «: parts of gold are themselves gold; in contrast, parts of chairs are not themselves chairs. The noun "gold« does not take a plural form or an indefinite article (»a«) and so gold per se is not countable, whereas »chair « does take a plural form and an indefinite article. So if gold is in a certain space, then gold itself is also in a part of that space. ${ }^{21}$

Some English nouns can be employed in both a mass and a count sense. I can say »there's chicken in the fridge«, and since parts of chicken can still be chicken we can each have chicken. However, if I say »there's $a$ chicken in the fridge « it doesn't follow that we can each have $» a$ chicken «. All this is admittedly oversimplification, but the main idea is clear. Mass terms afford a means of talking about substances that treats wholes and parts as on a par.

Let us now return to Mullins's idea of absolute space and time as attributes of God. Accordingly, physical space and time (which conjointly is identical to and/or contains the universe) is in absolute space and time; moreover, as I argued in the discussion of Figure 2a above, in order to distinguish panentheism from theism we need to construe this in-ness as substantive parthood. But if God is considered in his masslike aspect, we can say as we did for gold, that God himself, qua his attribute of absolute space, is in whatever the absolute space encompasses, viz. the physical space and all its contents, parts, and constituents.

I used the term »masslike« in the preceding paragraph because I want to acknowledge that there would have to be an important difference between the use of »God « as a mass noun and ordinary physical mass nouns such as "gold «. When we talk of a mass of the substance gold, it occupies space and ipso facto subspaces (or parts) of that space. The problem with this picture is that although we can say that what a subspace contains is itself gold, we would

20 Pfeifer 2016: n. 5. Also cf. n. 14 above.

21 Although not in every part of the space; real gold is not infinitely divisible, so at the atomic level we will have parts of gold that are not gold. In our physical realm, there may not actually be anything that is infinitely divisible while retaining its substancehood or identity, not even physical space. 
be committed to the consequence that some subspaces will contain more gold or less gold than others. ${ }^{22}$ Clearly this is not the sort of thing we want to say about God. When God is omnipresent, he is completely present everywhere, not present in varying quantities. So the analogy with mass terms for some uses of »God « needs further qualification.

Here are two additional manoeuvres we might make to explain why »God « doesn't entirely behave like "gold «. The first is that we might say that the substance that is God, whatever it comes to, is a constant throughout both absolute and physical space and time. Even as the speed of light is a constant such that two photons moving in opposite directions from a common light source would nevertheless move away from each other with a relative velocity of just the speed of light and not twice the speed of light, similarly when God is in a space (whether absolute or physical), he is fully present in all the subspaces. God's total »there-ness « is a constant that cannot be exceeded or diminished by the different spaces in which he is present. The second manoeuvre might be simply to say that, unlike gold, God is not subject to the metrics of the spaces he is in at all; familiar notions of distance, area, or volume just don't apply to him.

\section{Quo Vadimus?}

I have attempted herein to present a coherent view of panentheism that eschews Pickwickian senses of »in « and aligns itself with, and builds upon, popular diagrammed portrayals of panentheism. So we began this disquisition by going along with the common spatial-locative characterization of panentheism and paying heed to some typical accompanying diagrams. But apart from their role as visual aids, we might also consider what kinds of diagrams these are. The two-dimensional circles of planar Euclidean geometry have finite and measurable circumferences; such geometric properties are not properties of God, nor do they make for the best metaphors or similes for properties of God. ${ }^{23}$ So these visual aids, if taken too literally, inadvertently reflect the opposite of what we might wish for in a characterization of God.

\footnotetext{
22 Methanks Graham Oppy for this reminder.

23 It is not my intention here to belabor the obvious. I merely want to highlight the idea that the geometric properties of the diagrams stand metaphorically for certain features of God that might be better captured by a more abstract but nevertheless still spatial representation.
} 
Although we may be naturally inclined towards spatial metaphors that are inherently geometrical and typically Euclidean, I would like to recommend that we prescind from such metaphors and the particular realizations of substances that they implicate. Rather than the geometrical spatial metaphors, I think we should focus on spatiality at the more abstract level of topological spaces, ${ }^{24}$ of which Euclidean and other geometrical spaces are merely special cases. From a topological point of view, for example, God could be conceived of as (having the attribute of) a non-metrizable space that contains a metric or metrizable space, viz. the universe. Or else, God might be associated with a so-called pseudometric space, i.e. a space in which the distance between nonidentical points can be zero. Moreover, topological concepts can be combined with mereological concepts (ergo »mereotopology«). Some philosophers have disparaged the idea that mereology might be used to say anything distinctive or interesting about panentheism, but it seems to me that mereology is amenable to many clever axiomatizations and shouldn't be written off prematurely. Indeed, recent mereological work on conceptions of location may be fruitful, inasmuch as it addresses such issues germane to the nature of God as whether substances can interpenetrate, whether substances can be multilocated, and whether an entity can be an extended simple. ${ }^{25}$ Such topological or mereological possibilities are not obviously at variance with Mullins's proposal and the additional views I have advanced. They merely represent a turn towards a more abstract and exact idiom that could be to our behoof.

\section{7. $\quad$ References}

Borg, M.J. (1997) The God We Never Knew: Beyond Dogmatic Religion to a More Authentic Contemporary Faith. San Francisco, CA: Harper.

Bracken, J.A. (2000) »Prehending God in and through the World.« Process Studies 29.1, 4-15. Online at: http://www.religion-online.org/article/prehending-god-in-andthrough-the-world/. Accessed 2018-03-18.

Britannica (2016):»Field theory.« Online at https://www.britannica.com/science/fieldtheory-psychology. Accessed 2018-03-11.

Chalmers D. (2016) »Panpsychism and Panprotopsychism.«In: Godehard Bruntrup and Ludwig Jaskolla (eds.) Panpsychism: Contemporary Perspectives. New York: Oxford University Press, 19-47.

24 Cf. Skowron 2015. Skowron surveys the use of various topological concepts in philosophizing about God, but unfortunately he does not specifically confront panentheism.

25 Gilmore 2018. 
Clayton, P. (2004) »Panentheism Today: A Constructive Systematic Evaluation.« In: P. Clayton and A. Peacocke (eds.) In Whom We Live and Move and have our Being: Panentheistic Reflections on God's Presence in a Scientific World. Grand Rapids, MI: Wm. B. Eerdmans Publishing Company, 248-264.

Clayton, P. (2010) »Panentheisms East and West.« Sophia 49, 183-191

Copleston, F.C. (1961) Aquinas. Baltimore, MD: Penguin Books.

Gilmore, C. (2018) »Location and Mereology.« In: E.N.Zalta (ed.) The Stanford Encyclopedia of Philosophy. Online at: https://plato.stanford.edu/archives/spr2018/ entries/location-mereology

Göcke, B.P. (2013a) »On the Importance of Karl Christian Friedrich Krause's Panentheism. "Zygon:Journal of Religion and Science 48, 364-379.

Göcke, B.P. (2013b) »Panentheism and Classical Theism.«Sophia 52, 61-75.

Göcke, B.P. (2018) The Panentheism of Karl Christian Friedrich Krause (1781-1832): From Transcendental Philosophy to Metaphysics. Oxford: Peter Lang. [openly accessible on the publisher's website].

Krause, K.C.F. (1828) Vorlesungen über das System der Philosophie. Göttingen: Dieterich'sche Verlagsbuchhandlung.

Martin, C.B. (1969) »People.« In: R. Brown and C.D. Rollins (eds.) Contemporary Philosophy in Australia, London: George Allen and Unwin, 158-172.

Mullins, R.T (2016) »The Difficulty with Demarcating Panentheism.« Sophia 55, 325-346

Pfeifer, K. (2016) »Pantheism as Panpsychism.« In: A.A. Buckareff and Y. Nagasawa (eds.) Alternative Concepts of God: Essays on the Metaphysics of the Divine, New York: Oxford University Press, 41-49.

Sharpe, L. (1991) Friedrich Schiller: Drama, Thought and Politics. Cambridge: Cambridge University Press.

Skowron, B. (2015) »The Explanatory Power of Topology in the Philosophy of God.«In: M. Szatkowski (ed.) God, Truth and Other Enigmas, Berlin/Munich/Boston: Walter de Gruyter, 241-253.

Strawson, P.F. (1959) Individuals: An Essay in Descriptive Metaphysics. London: Methuen. 